\title{
The Endocannabinoid System, Cannabinoids, and Pain
}

\author{
Perry G. Fine, M.D. ${ }^{1 *}$ and Mark J. Rosenfeld, M.S., Ph.D. ${ }^{2}$ \\ ${ }^{\prime}$ Professor of Anesthesiology, Pain Research and Management Centers, Department of Anesthesiology, \\ School of Medicine, University of Utah, Salt Lake City, Utah, USA; and ${ }^{2}$ Chief Executive Officer, ISA \\ Scientific, Draper, Utah, USA
}

\begin{abstract}
The endocannabinoid system is involved in a host of homeostatic and physiologic functions, including modulation of pain and inflammation. The specific roles of currently identified endocannabinoids that act as ligands at endogenous cannabinoid receptors within the central nervous system (primarily but not exclusively $\mathrm{CB}_{1}$ receptors) and in the periphery (primarily but not exclusively $\mathrm{CB}_{2}$ receptors) are only partially elucidated, but they do exert an influence on nociception. Exogenous plant-based cannabinoids (phytocannabinoids) and chemically related compounds, like the terpenes, commonly found in many foods, have been found to exert significant analgesic effects in various chronic pain conditions. Currently, the use of $\Delta 9$-tetrahydrocannabinol is limited by its psychoactive effects and predominant delivery route (smoking), as well as regulatory or legal constraints. However, other phytocannabinoids in combination, especially cannabidiol and $\beta$-caryophyllene, delivered by the oral route appear to be promising candidates for the treatment of chronic pain due to their high safety and low adverse effects profiles. This review will provide the reader with the foundational basic and clinical science linking the endocannabinoid system and the phytocannabinoids with their potentially therapeutic role in the management of chronic pain.
\end{abstract}

KEY WORDS: Cannabinoids, cannabinoid receptors, chronic pain, endocannabinoid system, phytocannabinoids

\footnotetext{
Abbreviations: $\mathrm{CB}_{1}$ and $\mathrm{CB}_{2}$, cannabinoid receptors 1 and 2, respectively; $\mathrm{CBD}$, cannabidiol; THC, delta-9tetrahydrocannabinol.

Citation: Fine PG, Rosenfeld MJ. The Endocannabinoid System, Cannabinoids, and Pain. Rambam Maimonides Med J 2013;4 (4):eoo22. doi:10.5041/RMMJ.10129

Copyright: (C) 2013 Fine and Rosenfeld. This is an open-access article. All its content, except where otherwise noted, is distributed under the terms of the Creative Commons Attribution License (http://creativecommons.org/licenses/by/3.0), which permits unrestricted use, distribution, and reproduction in any medium, provided the original work is properly cited.
}

Conflict of interest: Dr Fine serves on the Board of Directors of the American Academy of Pain Medicine and ISA Scientific. Dr Rosenfeld serves on the Board of Directors of ISA Scientific.

* To whom correspondence should be addressed. E-mail: perry.fine@hsc.utah.edu 
Pain is an unpleasant, commonly occurring, and universal human experience; it is also a very complex phenomenon. The experience of pain and the resultant emotional state depends as much or perhaps more on the contextual circumstances (how, when, where, and why) of the pain-inciting event as the intensity of the noxious stimulus. And a seemingly similar pain-producing event may be experienced (and communicated) quite differently from person to person, situation to situation, and among various cultures. The neurophysiology of acute pain due to a brief single noxious event is best understood. The nociceptive components of the peripheral and central nervous systems are highly refined to signal warnings of potential or actual tissue damage; reflex and conscious responses are usually adaptive for self-protection. Fortunately, most occurrences of pain are self-limited, resolving quickly with discontinuation of the noxious stimulus or in tandem with tissue healing or resolution of the insult to somatic or visceral structures.

But pain that continues relentlessly due to ongoing nociceptive stimulation from unresolved disease (nociceptive pain) or pathophysiological changes within the nervous system (neuropathic pain) serves little purpose. In contrast to acute pain, unresolved pain leads to subliminal and conscious reflex responses that are often maladaptive (Figure 1). ${ }^{\text {It }}$ imparts a tremendous burden on the pain sufferer's health, social interactions, occupational performance, emotional state, and finances. In turn, chronic pain incurs a significant direct and indirect financial toll on society (Figure 2). In evaluating the prevalence and impact of pain, a recent report by the National Academy of Sciences' Institute of Medicine concluded that pain-related medical services and loss of productivity cost the United States economy close to one trillion US dollars annually when painrelated costs associated with patients in long-term care and within the military are included. ${ }^{2}$

The prevalence of persistent, debilitating pain is increasing, commensurate with advances in trauma care that allow survival after serious injury and medical care that slow disease progression, or transform imminently life-threatening diseases into chronic progressive conditions, or provide a cure but with residual morbidity. Similarly, the growing proportion of older individuals in economically developed and developing nations, and the propensity to develop chronic pain-producing conditions with

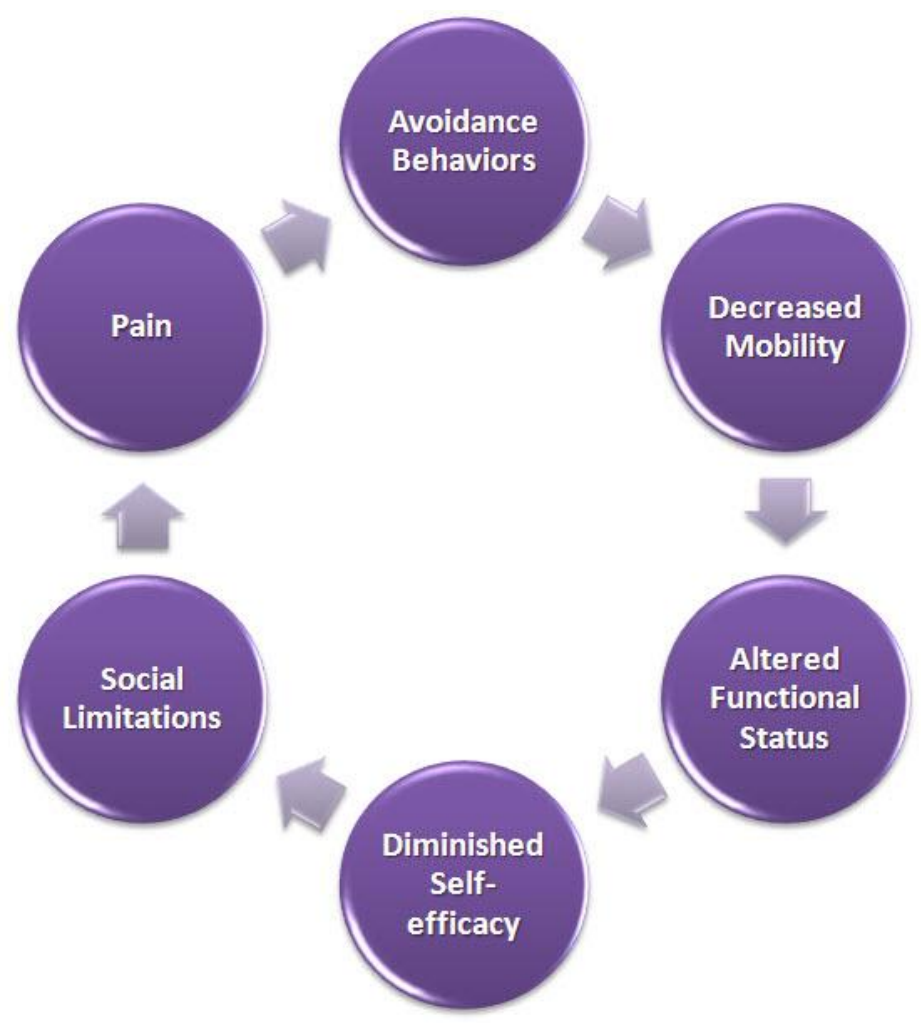

Figure 1. The Vicious Cycle of Pain. 
advancing age (e.g. osteoarthritis, degenerative spine disease, vasculopathy, diabetes mellitus, and cancer), is leading to a high prevalence of chronic pain worldwide.

Unfortunately, currently available analgesic medications and pain-modulating procedures are severely limited by combinations of low efficacy, excessive toxicity/risk/safety concerns, insufficient access to care, or unbearable cost. In patients with chronic pain, and especially neuropathic pain, "success" is measured in small increments of improvement among limited numbers of patients. In randomized clinical trials of analgesics for neuropathic pain, no more than half of patients experi- ence clinically meaningful pain relief from pharmacotherapy. ${ }^{3}$ More effective and universally available means to prevent and treat chronic pain are needed, regardless of the primary or inciting cause. Against this background of extraordinary need, this paper will provide an overview of the developing basic and clinical science of cannabinoid pharmacology, and the potential therapeutic value of cannabinoids for chronic pain management. 4,5

The first portion of this article presents a very basic review of the pharmacology of the cannabinoids and endocannabinoid receptor system, drawing both from animal and human models. ${ }^{6}$ Although cannabinoids have putative therapeutic

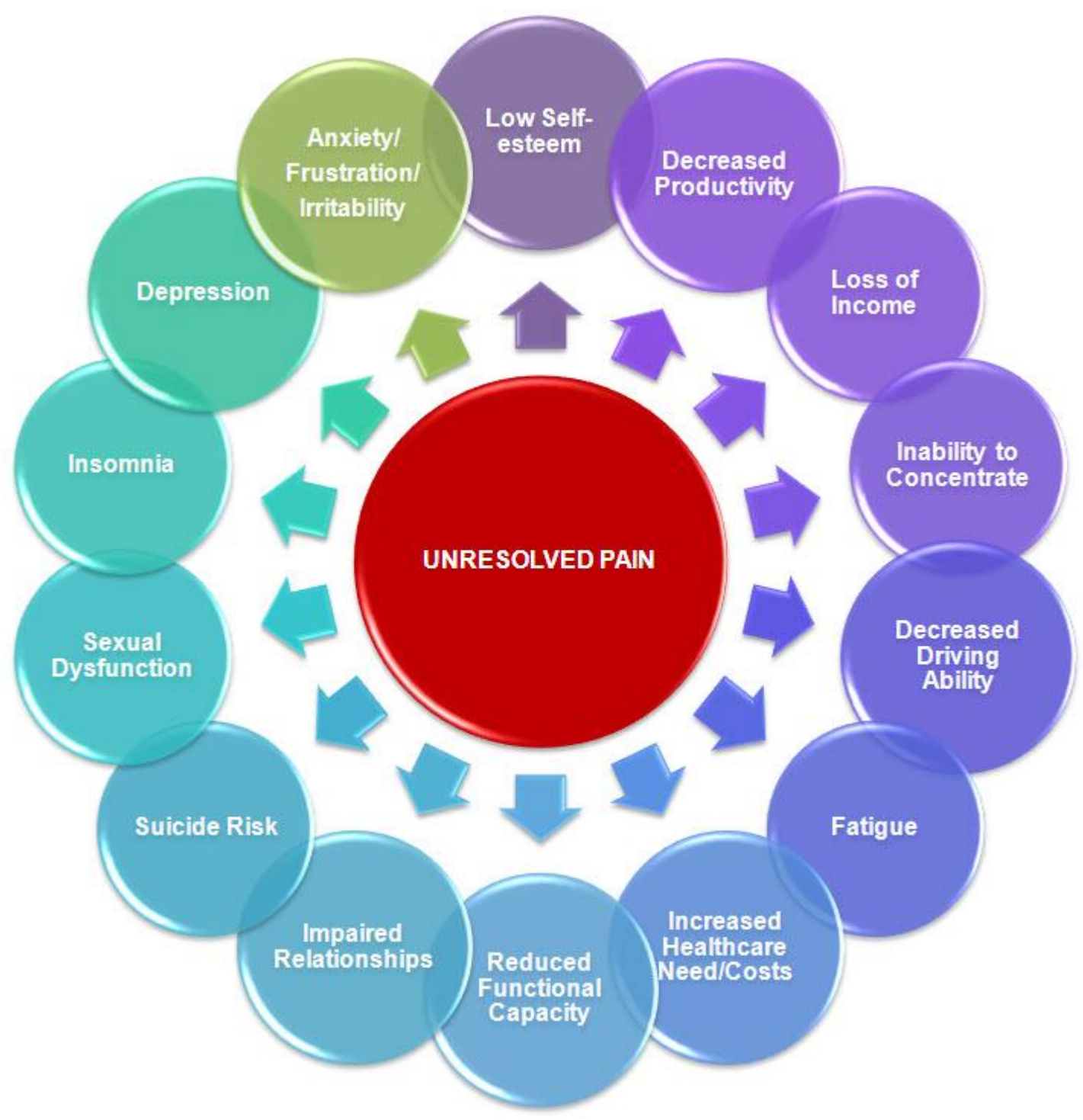

Figure 2. Consequences of Unresolved Pain. 
effects in a wide variety of clinical conditions, some of which (e.g. diabetes) are associated with chronic painful conditions, the focus herein is on the effect of cannabinoids on pain rather than on other pathophysiological states. This introduction will pave the way to insight and understanding of the potential role of this class of agents in pain control. Other than to understand basic mechanisms and to formulate hypotheses of safety and efficacy, experience has shown us that animal or human experimental pain investigations poorly predict responses to analgesic therapies in "real life" situations. From this perspective, the second part of this review focuses on pain relief in the clinical setting, and only the human experience will be described.

Extensive research and prolonged exposure to cannabinoids both in animals and humans have addressed important questions about safety. Cannabinoids have a very high therapeutic index. In fact, it is virtually unlimited insofar as fatalities have not been reported directly related to the toxicity of any cannabinoid, even with extremely high dosing. However, there are potentially severe cognitive, psychotomimetic, and substance abuse-related adverse effects associated with $\Delta$ 9-tetrahydrocannabinol (THC) exposure that must be taken seriously, especially in young or cannabis-naïve patients. ${ }^{-17}$

In medicinal use, these adverse effects may be prevented or mitigated by avoiding THC entirely in favor of other non-psychoactive cannabinoids. ${ }^{18}$ For instance, prolonged exposure to the non-psychoactive phytocannabinoid, cannabidiol (CBD), at doses of 3-4 mg/kg/d, both in human volunteers and those with epilepsy, revealed no adverse effects or evidence of toxicity. ${ }^{19}$ However, adequate precaution must be taken when $\mathrm{CBD}$ is used in conjunction with many other drugs due to its inhibition of several cytochrome $\mathrm{P} 450$ isoenzymes, including CYP1A2, CYP2B6, CYP2C9, CYP2D6, and CYP3A4. This is especially important in the management of chronic pain, since many conventionally used analgesics (opioids and non-opioids) are metabolized via these pathways (most notable CYP2D6 and $\mathrm{CYP}_{3} \mathrm{~A}_{4}$ ). ${ }^{20}$ Therefore, the key relevant clinical issues for practitioners dealing with populations of patients in pain have to do with questions about effects of specific cannabinoids, their various modes of delivery and absorption, potential indications, and their respective risks and tolerability. ${ }^{21}$

Based on relatively new but limited scientifically based literature, it is now only possible to speculate about mechanisms of action and what the future may hold for phytocannabinoids as effective analgesics across the vast and varied cohorts of people living with chronic pain. With that in mind, this review will proceed with a summary of what is known about different cannabinoid congeners on various types of pain (efficacy and tolerability) and the putative role of commonly available "generally regarded as safe" (GRAS) ingredients that may enhance the effectiveness of certain phytocannabinoids.

\section{CANNABIS AND CANNABINOIDS: PAST TO PRESENT}

Cannabinoid refers to a pharmacological class of about 60 naturally occurring compounds (phytocannabinoids) found in plants of the genus Cannabis (i.e. marijuana and hemp) and structurally related synthetic analogues (e.g. $\Delta 3,4$-tetrahydrocannabinol and HU-210, which is $100-800$ times more potent psychoactively than natural $\mathrm{THC}^{22}$ ). This classification has been generalized to include a wide range of exogenous and endogenously produced compounds that exhibit similar pharmacodynamic properties as the phytocannabinoids or demonstrate activity at the same receptor binding sites. Cannabis sativa has two subspecies, indica and sativa. A variety of the former, hemp, has industrially and nutritionally useful qualities. Hemp has a very low amount of the psychoactive constituent $\Delta 9$-tetrahydrocannabinol (THC) but higher quantities of cannabidiol (CBD) which may offer a range of medicinal benefits without the cognitive effects and abuse potential associated with THC. 23

Cannabis has a long and storied social and medicinal history dating back thousands of years. ${ }^{24,25}$ Regulations restricting Cannabis cultivation and distribution, especially as these pertain to marijuana, have preoccupied governments from China, through India to Europe and Great Britain, and across the Atlantic to the Americas for centuries due to its inherent psychedelic intoxication. ${ }^{26}$ The emotional and cognitive effects of Cannabis have mostly been sought for recreational or ritualistic purposes, and are commonly derived from smoking dried plant material or its concentrated oily derivative, hashish. Even though hemp has minimal potential psychoactivity, it is nonetheless subjected to the same restrictions as marijuana in many jurisdictions.

Only recently have we gleaned scientific insight into several of the pharmacologically distinct 
cannabinoids and their effects at specific receptors within various animals and humans. In 1997 both the United States National Institutes of Health and the British Medical Association released reports on the potential therapeutic uses of Cannabis and cannabinoids. Notwithstanding the momentous breakthrough represented by these reports in support of the potential value of cannabinoids for medical use, the health hazards of smoking coupled with the cognitive-behavioral effects of Cannabis have created political and regulatory obstacles worldwide, with regard to evaluating cannabinoids as medicines and mainstream health care professionals' acceptance of Cannabis as a legitimate therapeutic agent. Fortunately, as the sciences of drug delivery and cannabinoid pharmacology have progressed in recent years, there are rapidly evolving technologies that will facilitate or enhance the medically indicated use of this pharmacological class of agents while overcoming the barriers imposed by unwanted or harmful psychoactive effects of Cannabis and smoking it as the only effective way to obtain adequate blood levels of cannabinoids. ${ }^{27}$

The potential value of the cannabinoids for medicinal purposes arose from the discovery ${ }^{28}$ and later cloning of endogenous cannabinoid receptors. ${ }^{29,30}$ The two major receptor types, $\mathrm{CB}_{1}$ (mostly in the central nervous system) and $\mathrm{CB}_{2}$ (mostly in peripheral tissues), are differentiated by their physiological actions and locations within the body. These are members of the seven transmembrane Gprotein coupled receptor superfamily which comprise the binding sites for almost half of all contemporary drugs. ${ }^{1}$

\section{THE ENDOCANNABINOID SYSTEM: RECEPTORS AND ENDOGENOUS RECEPTOR LIGANDS}

The endogenous cannabinoid system has been described as "an ancient lipid signaling network which in mammals modulates neuronal functions, inflammatory processes, and is involved in the etiology of certain human lifestyle diseases, such as Crohn's disease, atherosclerosis and osteoarthritis. The system is able to downregulate stress-related signals that lead to chronic inflammation and certain types of pain, but it is also involved in causing inflammation-associated symptoms, depending on the physiological context." ${ }^{2}$

\section{$\mathrm{CB}_{1}$ Receptors}

The $\mathrm{CB}_{1}$ receptor has been cloned from humans.33 Activation of $\mathrm{CB}_{1}$ receptors leads to dose-dependent and stereo-selective inhibition of adenylate cyclase activity, thus affecting memory, perception, and movement. The $\mathrm{CB}_{1}$ receptor appears to be responsible for the mood-enhancing effects of Cannabis as well as negative, dysphoria-inducing, and frank psychotomimetic effects in susceptible individuals.

$\mathrm{CB}_{1}$ receptor distribution has been well characterized in the human brain. 34 The receptors are expressed in high abundance in the hippocampus and associational cortical regions, the cerebellum, and the basal ganglia. This widespread distribution in the brain matches well with the known pharmacodynamic effects of cannabinoids. In contrast, binding is sparse or absent from the brain stem, medulla, and thalamus. The paucity of $\mathrm{CB}_{1}$ receptors in these areas helps explain the absence of life-threatening effects on vital physiological functions associated with extremely high doses of cannabinoids.

Besides the brain, the $\mathrm{CB}_{1}$ receptor occurs in the testis, and presynaptically on sympathetic nerve terminals. $35 \mathrm{CB}_{1}$ receptor mRNA has been identified in the adrenal gland, heart, lung, prostrate, bone marrow, thymus, and tonsils. ${ }^{36,37}$

\section{$\mathrm{CB}_{2}$ Receptors}

Although $\mathrm{CB}_{1}$ and $\mathrm{CB}_{2}$ receptors share considerable structural similarities, their distribution and activity diverge. Among other actions, including pain modulation, $\mathrm{CB}_{2}$ receptors are thought to serve an important role in immune function and inflammation. ${ }^{8}$ There is ample evidence that $\mathrm{CB}_{2}$ receptor activation reduces nociception in a variety of preclinical models, including those involving tactile and thermal allodynia, mechanical and thermal hyperalgesia, and writhing. 39 With regard to their role in modulating neuropathic pain, the presence of $\mathrm{CB}_{2}$ receptors on microglia within the nervous system may explain the putative benefits of cannabinoids in reducing cytokine-mediated neuroinflammation.

$\mathrm{CB}_{1}$ and $\mathrm{CB}_{2}$ receptors inhibit adenylate cyclase via interactions at the G-protein complex. However, their activation and consequent inhibition of various ion channels differs. $4^{\circ}$ The key point is that differential binding of $\mathrm{CB}_{1}$ or $\mathrm{CB}_{2}$ receptors, either separately or in combination by their respective 
endogenous or exogenous ligands, leads to varied physiological effects (Table 1), mediated via several neurotransmitters, including acetylcholine, glutamate, and dopamine.

\section{ENDOGENOUS CANNABINOIDS AND NOCICEPTION}

The first compound to be identified as an endogenous cannabinoid receptor ligand was given the name anandamide, after the Sanskrit word for "bliss." Anandamide (Figure 3) bears no chemical resemblance to the aromatic phytocannabinoids such as THC and CBD, but rather is an arachidonic acid derivative. ${ }^{41}$ Several other endogenously generated moieties have been identified that bind to cannabinoid receptors (collectively known as endocannabinoids), but their roles in homeostatic functions and in disease states remain poorly defined. The physiologic role of anandamide continues to be actively explored, having been identified in central and peripheral tissues of man. ${ }^{2}$

It appears that the endocannabinoid system is intimately involved in tissue healing in the face of inflammatory conditions, correlating clinically with prevention and treatment of inflammation-mediated pain. 43 With regard to potential pain-modulating activity, anandamide has been shown to be a full agonist at vanilloid $\left(\mathrm{TRPV}_{1}\right)$ receptors and may play
Table 1. Physiological Actions Mediated by Activation or Inhibition of Cannabinoid Receptors.

\section{Physiological Actions}

1. Antinociception

2. Cognition and memory

3. Locomotor activity

4. Endocrine functions

5. Temperature control and heart rate

6. Nausea and vomiting

7. Intraocular pressure

8. Inflammation

9. Immune recognition and antitumor effects

a modulating role at other transient receptor potential (TRP) receptor types. 44 Anandamide is reported to produce effects similar to $\mathrm{THC}$ at $\mathrm{CB}_{1}$ receptors, via G-protein coupled inhibition of adenylate cyclase. These effects include antinociception, hypomotility, and reduced memory. 45

However, there appear to be distinct differences between anandamide and other cannabinoids with respect to their antinociceptive properties and other physiological effects which vary as a function of

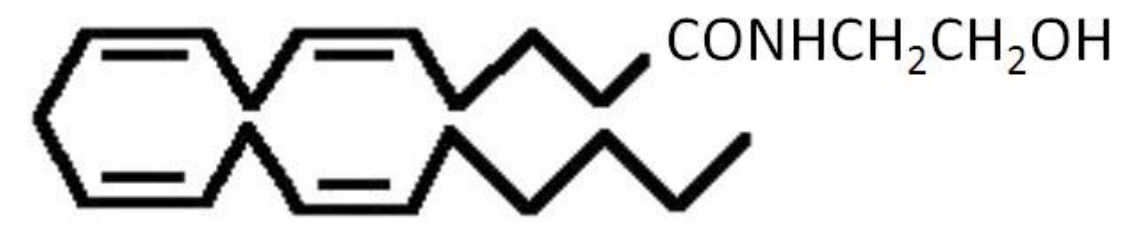

Anandamide

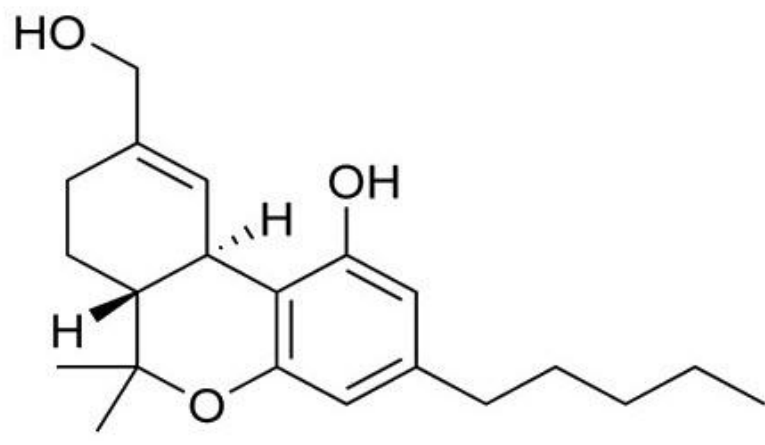

$\Delta$ 9-tetrahydrocannabinol (THC)

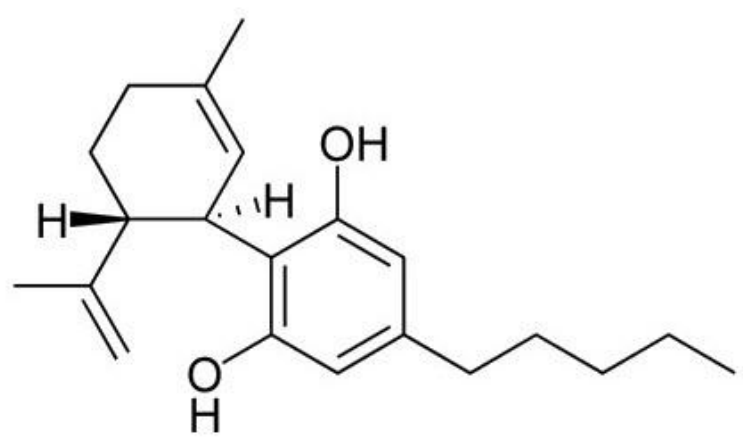

Cannabidiol (CBD)

Figure 3. Chemical Structures of Anandamide, $\Delta 9$-Tetrahydrocannabinol, and Cannabidiol. 
route of administration. It is not known whether anandamide acts at the same sites as phytocannabinoids to produce antinociception. The behavioral effects of THC and anandamide after administration suggest that they act, at least in part, in the brain and/or spinal cord. These studies suggest that anandamide is less potent and has a shorter duration of action than THC. 46

Studies have demonstrated that antinociceptive effects of cannabinoids are mediated through mechanisms distinct from those responsible for other behavioral effects. For instance, THC has additive analgesic efficacy with kappa opioid receptor agonists. This effect is blocked by kappa antagonism, but opioid receptor antagonism does not alter the psychoactive effects of THC. 47 Investigations into the endogenous cannabinoids and their effector sites (including $\mathrm{CB}_{1}$ and $\mathrm{CB}_{2}$ along with other noncannabinoid receptors) have exploded in recent years, and insights reveal this area of pharmacology to be highly complex and dynamic. For instance, there is mounting evidence that endogenous and exogenous cannabinoids exert some influence on opioid, $5 \mathrm{HT}_{3}$, and $\mathrm{N}$-methyl-d-aspartate receptors. These interactions suggest a role for endocannabinoids in homeostatic pain modulation (antinociception), thus their use as exogenous agents in pain management. 48

Most recently, Thiago et al.49 provided evidence that the cannabinoid agonists anandamide and $\mathrm{N}$ palmitoyl-ethanolamine (PEA) induce peripheral antinociception activating $\mathrm{CB}_{1}$ and $\mathrm{CB}_{2}$ receptors, respectively, stimulating the endogenous noradrenergic pathway which in turn activates peripheral adrenoreceptors, inducing antinociception. Other studies have demonstrated the expression of functional $\mathrm{CB}_{2}$ receptors in areas of human dorsal root ganglion (DRG) sensory neurons. $\mathrm{CB}_{2}$ receptor expression also has been demonstrated in the spinal cord as well as in other brain regions particularly relevant for nociceptive integration. 50-52 $^{52}$

These findings implicate $\mathrm{CB}_{2}$ receptors in the analgesic effects produced by $\mathrm{CB}_{2}$ agonists.53,54 Other evidence for the involvement of the endocannabinoid system in peripherally mediated pain control includes the finding that $\mathrm{CB}_{2}$ receptor agonists can evoke analgesia by triggering the release of beta-endorphin in response to the stimulation of $\mathrm{CB}_{2}$ receptors expressed in human keratinocytes. 55 Many other studies have linked cannabinoid and opioid effects through primary receptor interactivity as well as downstream second messenger effects. From a clinical standpoint, this may provide an opportunity for therapeutic synergy. ${ }^{56}$

The role of $\mathrm{CB}_{2}$ receptors in antinociception has been demonstrated in inflammatory and neuropathic pain models. Investigations involving carrageenan-induced inflammatory pain in rodents demonstrate that activation of $\mathrm{CB}_{2}$ receptors by $\mathrm{CB}_{2}-$ selective agonists suppresses neuronal activity in the dorsal horn via reduction in C-fiber activity and wind-up involving wide dynamic range (WDR) neurons.57,58 The involvement of cannabinoid receptors in modulating pain has been supported further by findings that there are increases in peripheral $\mathrm{CB}_{2}$ receptor protein or mRNA in inflamed tissues and in the dorsal root ganglion in neuropathic states. ${ }^{59-61}$ Data from studies investigating viscerally induced pain due to colorectal distension indicate that peripheral $\mathrm{CB}_{1}$ receptors mediate the analgesic effects of cannabinoids on visceral pain from the gastrointestinal tract. ${ }^{62}$

It may now be concluded that cannabinoids play a role in endogenous (homeostatic) modulation of nociception, and that exogenous cannabinoids potentially offer some degree of analgesia in various pain states. ${ }^{63}$ With this foundation to build upon, the proceeding section will explore the role of cannabinoids in clinical pain relief in humans. Much has been learned since a decade ago when there was significant doubt about translating research findings linking cannabinoids to antinociception from "bench to bedside."64 There are now methodically sound studies that may lead to important therapeutic advances for people living with pain.

\section{CANNABINOIDS AND THE MANAGEMENT OF PAIN}

Evidence continues to accumulate suggesting that cannabinoids can impact normal inhibitory pathways and pathophysiological processes influencing nociception in humans.59,65 When cannabinoids do have an analgesic effect, it is more likely to occur in hyperalgesic and inflammatory states. ${ }^{66}$ Clinical trials lasting from days to months, involving more than 1,00o patients, have shown efficacy in different categories of chronic pain conditions (Table 2), but the vast majority of controlled trials have involved patients with chronic neuropathic pain. ${ }^{67-78}$

When cannabinoids lead to a reported reduction in pain, it remains unclear where the effects are triggered, or which aspect of the pain experience is 


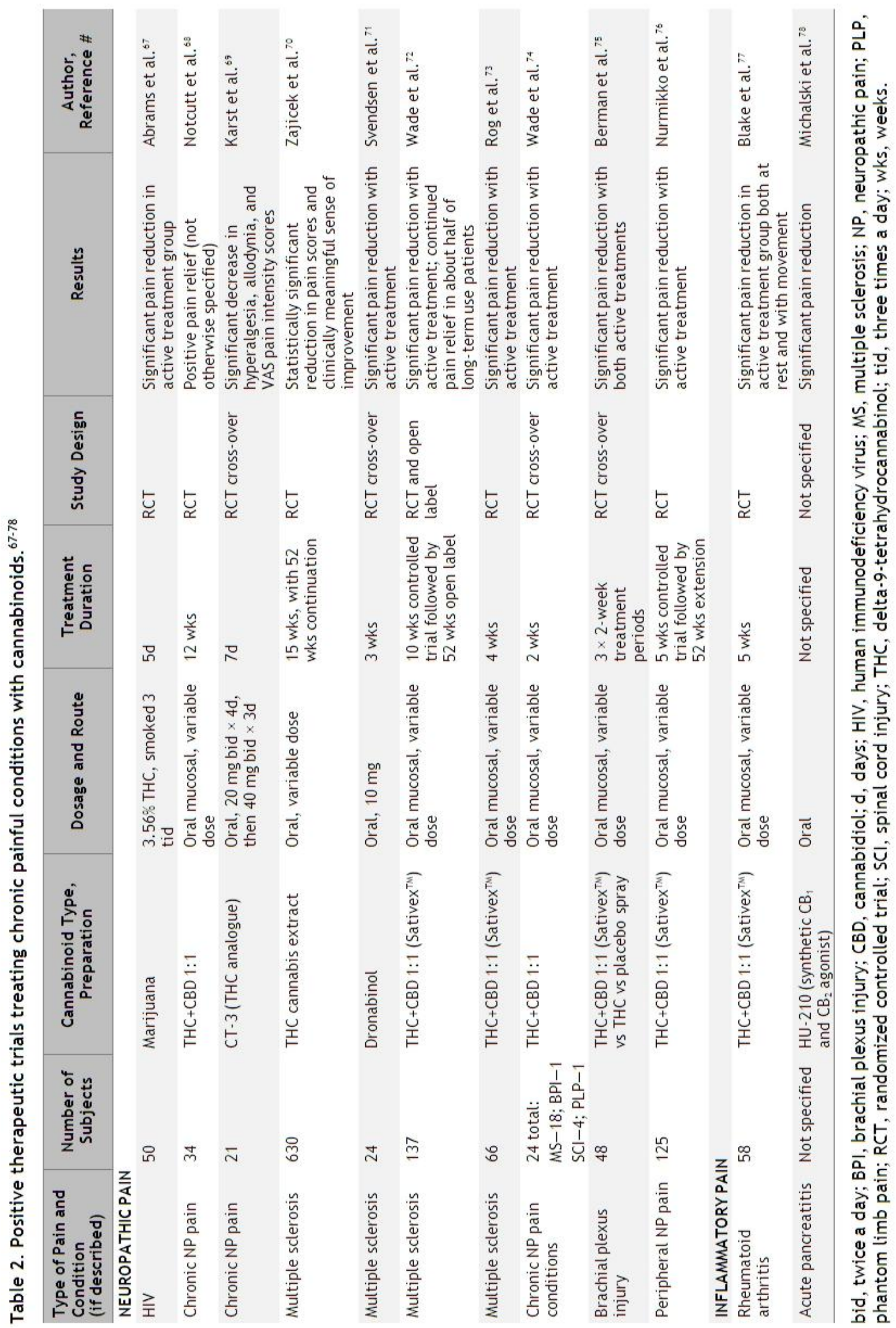


most affected and under what circumstances. As well, different cannabinoids may lead to mechanistically different pain-relieving effects. For instance, a recent study of functional brain imaging in human volunteers investigated the means by which THC may influence pain resulting from capsaicin-induced hyperalgesia. The study results suggest that "peripheral mechanisms alone cannot account for the dissociative effects of THC on the pain that was observed. Instead, the data reveal that amygdala activity contributes to inter-individual response to cannabinoid analgesia, and suggest that dissociative effects of THC in the brain are relevant to pain relief in humans."79 In other words, cannabinoids, and THC in particular, may have differential effects on the sensory (e.g. intensity; quality) versus affective (e.g. unpleasantness; suffering) components of pain.

The two best-studied cannabinoids implicated as having potential analgesic properties are THC and CBD (Figure 3). THC was first isolated from Cannabis by Raphael Mechoulam and colleagues in 1964 at the Hebrew University of Jerusalem, and they identified it as the major psychoactive component of Cannabis, with preferential binding at $\mathrm{CB}_{1}$ receptors. ${ }^{80}$ Synthetic forms of THC, like dronabinol and nabilone, are commercially available in several countries, and are considered controlled substances. These have indications for treating anorexia in AIDS patients and as a therapy for intractable nausea and vomiting during cancer chemotherapy. In a wide range of oral doses, dronabinol, which is chemically identical to the THC extracted from plants, has not demonstrated significant pain relief in several naturally occurring and experimental pain conditions. ${ }^{81-83}$ In contrast, nabilone, which is chemically similar to THC but not identical, 84 has demonstrated modest efficacy in fibromyalgia 85 but with dose-limiting adverse effects. Its use has led to paradoxical increases in pain in the postoperative setting. 86

Cannabidiol is a major constituent of Cannabis. It has virtually no psychoactivity compared against THC. 87 Cannabidiol has low affinity for both cannabinoid $\mathrm{CB}_{1}$ and $\mathrm{CB}_{2}$ receptors. Limited pharmacodynamic effects due to relatively weak receptor binding (low affinity) may be overcome with higher doses of agonist. Whereas the dose-limiting factor with THC resides in the highly variable propensity among individuals to experience and tolerate negative affective, cognitive, and psychotomimetic effects, the ability of cannabidiol to behave as a $\mathrm{CB}_{1}$ receptor inverse agonist may contribute to its documented mitigating action on THC psychotomimetic effects. More recently it has been postulated that cannabidiol may exert its effects via inhibition of anandamide deactivation or otherwise enhancing anandamide signaling. ${ }^{88}$

Cannabidiol agonist activity at $\mathrm{CB}_{2}$ receptors seems to account for its anti-inflammatory properties and both primary and secondary influences on pain. ${ }^{89,90}$ As well, memory impairments associated with THC are not apparent with CBD, and, when combined, CBD reduces the negative impact of THC on memory. This mitigating effect also has been attributed to the inverse agonist effect at $\mathrm{CB}_{1}$ receptors by CBD. Anxiolytic effects of CBD may also be attributed to its agonist effect at the $5-\mathrm{HT}_{1 \mathrm{~A}}$ receptor. ${ }^{91}$

A pharmaceutical combination product of THC and CBD now exists as an oral spray consisting of 27 $\mathrm{mg} \Delta$ 9-tetrahydrocannabinol and $25 \mathrm{mg}$ cannabidiol per $\mathrm{mL}$ (100 microliters per administered dose; i.e. $2.7 \mathrm{mg}$ THC and $2.5 \mathrm{mg}$ CBD), extracted from Cannabis sativa $\mathrm{L}$. This formulation is approved in Canada, New Zealand, Israel, and several European countries (and possibly seeking US FDA approval in 2013) for the management of spasticity in multiple sclerosis (MS). There are several on-going trials on its efficacy in treating MS-related pain. ${ }^{92}$ Investigations of the therapeutic value of THC and THC-CBD via oral mucosal delivery in the treatment of various other neuropathic pain conditions show promising albeit modest results.5,73,75,93 The limited efficacy is likely due to the relatively low dose of this combination of cannabinoids. It is important to note that the dose-limiting factor is how much THC may be tolerated. With higher doses via smoking marijuana or inhaling vaporized Cannabis, hyperalgesic and cognitive effects become more pronounced and problematic, especially in cannabis-naïve individuals. ${ }^{94-98}$ Beyond these trials involving $\mathrm{CBD}$ and THC, comparative or head-to-head studies of individual cannabinoids or various cannabinoid combinations and routes of administration evaluating clinical outcomes are lacking.

\section{CANCER PAIN}

The therapeutic role of cannabinoids in cancer treatment, in terms of effects on tumor cells and on cancer pain, is of great interest. Correlations have been found between cannabinoid receptor levels and endocannabinoid activity and cancer severity, pain intensity, and survival.99 
For treating refractory cancer-related pain, there is mounting evidence that cannabinoids may be a useful addition to current analgesic treatments. However, to realize the full potential of cannabinoids suggested by preclinical data, it is likely that peripheral $\mathrm{CB}_{1}$ or $\mathrm{CB}_{2}$ receptors or modulation of endocannabinoids will have to be targeted to achieve analgesia without dose-limiting side effects. ${ }^{100,101}$ So far, studies of the efficacy of CBD in cancer pain (as well as in neuropathic pain) have used insufficient doses of CBD (alone or in combination with THC) to determine efficacy. ${ }^{102}$ Part of this insufficiency may be due to the poor bioavailability of cannabinoids. ${ }^{103}$

\section{COMBINING PHYTOCANNABINOIDS AND TERPENES: THE ENTOURAGE EFFECT}

The entourage effect is the term used to describe enhancement of efficacy, with related improvement in overall therapeutic effectiveness, derived from combining phytocannabinoids and other plantderived molecules. ${ }^{104}$ Besides CBD, phytocannabinoids that have been identified as exerting clinically useful effects without psychoactivity include tetrahydrocannabivarin, cannabigerol, and cannabichromene. Innovative conventional plant breeding has been yielding Cannabis chemotypes expressing high titers of each component for future study.

A chemical class known as the terpenes shares a precursor molecule with phytocannabinoids; they are all flavor and fragrance components common to human diets. Terpenes have been designated "generally recognized as safe" (GRAS) by the US Food and Drug Administration and other regulatory agencies. Cannabis-derived terpenes include limonene, myrcene, $\alpha$-pinene, linalool, $\beta$-caryophyllene, caryophyllene oxide, nerolidol, and phytol. ${ }^{105}$ These terpenes are also found in other plants.

Terpenes are quite potent and affect animal and even human behavior when inhaled in very low concentrations. They display unique therapeutic effects that may contribute meaningfully to the entourage effects of Cannabis-based medicinal extracts. Of particular interest are the phytocannabinoidterpene interactions that could produce synergy with respect to treatment of pain and inflammation. Phytocannabinoid-terpene synergy increases the likelihood that an extensive pipeline of new therapeutic products is possible from this age-old plant.

The synergistic contributions of cannabidiol to Cannabis pharmacology-and specifically analge- sia-have been scientifically demonstrated. Preclinical and clinical data indicate that cannabinoids administered together are more effective at ameliorating neuropathic pain than the use of a single agent. ${ }^{104,106}$

The terpene $\beta$-caryophyllene is found in a number of commonly available plants, including black pepper, cinnamon, clove, and other spices. It selectively binds to the $\mathrm{CB}_{2}$ receptor at nanomolar concentrations and acts as a full agonist. $\beta$ Caryophyllene and cannabidiol occur abundantly in Cannabis sativa. So this plant species produces at least two entirely different chemical substances able to target $\mathrm{CB}_{2}$ receptors differentially. While studies on the pharmacokinetics of $\beta$-caryophyllene are still on-going, it is already clear that this terpene is readily bioavailable. Unlike many polyphenolic natural products, it is not metabolized immediately but shows a Tmax $>1 \mathrm{~h}$ after one single oral administration. Orally administered $\beta$-caryophyllene $(<5$ $\mathrm{mg} \cdot \mathrm{kg}^{-1}$ ) produces strong anti-inflammatory and analgesic effects in wild-type mice but not in $\mathrm{CB}_{2}$ receptor knock-out mice, which is a clear indication that it may be a functional $\mathrm{CB}_{2}$ ligand.107

On-going studies show that $\beta$-caryophyllene is effective at reducing neuropathic pain in a $\mathrm{CB}_{2}$ receptor-dependent manner. ${ }^{108}$ Like other $\mathrm{CB}_{2}$ ligands $\beta$-caryophyllene inhibits the pathways triggered by activation of the toll-like receptor complex CD14/TLR4/MD2, which typically leads to the expression of pro-inflammatory cytokines (e.g. IL-1 beta, IL-6, IL-8, and TNF alpha) and promotes a Th1 immune response that plays a critical role in neuroinflammation, sensitization, and pain. ${ }^{109}$ Therefore, the FDA-approved food additive $\beta$-caryophyllene seems an attractive candidate for clinical trials targeting the $\mathrm{CB}_{2}$ receptor. Indeed, in cases of intractable or difficult-to-control pain, combination therapy with small doses of opioid and non-psychoactive cannabinoid receptor agonists may be an alternative way to circumvent the undesirable side effects of opioids yet obtain far greater analgesic efficacy than achieved with cannabinoids alone.56,110

\section{ADDITIONAL PAIN-RELATED THERAPEUTIC BENEFITS OF CANNABINOIDS}

Cannabinoids may have another therapeutic benefit in managing chronic pain, with regard to sleep. Not only does normalized sleep improve pain relief and mood disorders associated with both poor pain 
control and poor sleep patterns, but there is significant risk of sleep-disordered breathing associated with central nervous system (CNS) drugs used to treat chronic pain. ${ }^{111}$ Opioid analgesics are most problematic, especially if combined with other CNS depressants such as benzodiazepines. It has been reported that cannabinoids suppress sleep-related apnea. This is an important area for further research and clinical application both in sleep and pain medicine. ${ }^{112}$

\section{CONCLUSIONS}

The phytocannabinoids have efficacy in the treatment of various chronic pain conditions with greatest promise as a therapeutic adjunct in treating peripheral and central neuropathic pain and inflammation-mediated chronic pain. However, the smoked route of administration and the psychoactivity of THC-with associated concerns about abuse and long-term cognitive adverse effectscontinue to pose serious and significant barriers to obtaining benefit from Cannabis among most patients and acceptability among health care professionals and regulatory agencies.

A formidable barrier to oral bioavailability resides in the pharmacokinetics of naturally occurring and synthetic cannabinoids, but relatively slow elimination may provide clinical utility through prolonged duration of therapeutic effects once these agents gain entry into the systemic circulation. The phytocannabinoids are metabolized rapidly in the liver, undergoing extensive hepatic first-pass metabolism. ${ }^{113}$ Elimination of oral cannabinoids from plasma is biphasic with an initial half-life of approximately 4 hours, and the terminal elimination halflives are of the order of 24 to 36 hours or longer. Cannabinoids are distributed throughout the body; they are highly lipid-soluble and accumulate in fatty tissue. The release of cannabinoids from fatty tissue is responsible for the prolonged terminal elimination half-life. ${ }^{114-116}$

Putting these pharmacologic, clinical, and societal issues together, the direction for the future resides in the development of orally administered, highly bioavailable, non-psychoactive phytocannabinoid products that also take advantage of the entourage effect, to provide the millions of people living with debilitating pain a comparatively safe and effective form of relief.

\section{REFERENCES}

1. Costigan M, Scholz J, Woolf CJ. Neuropathic pain: a maladaptive response of the nervous system to damage. Annu Rev Neurosci 2009;32:1-32. Full Text

2. IOM Committee on Advancing Pain Research, Care, and Education Board on Health Sciences Policy Relieving Pain in America: A Blueprint for Transforming Prevention, Care, Education, and Research. Institute of Medicine of the National Academies, 2011. Available at: http://tinyurl.com/4377gws. Accessed March 23, 2013.

3. Dworkin RH, O'Connor AB, Audette J, et al. Recommendations for the pharmacological management of neuropathic pain: an overview and literature update. Mayo Clin Proc 2010;85:S3-14.

4. Beaver WT, Buring J, Goldstein A, Johnson K, Jones R. Workshop on the Medical Utility of Marijuana. In: Ad Hoc Group of Experts. Report to the Director. Bethesda, MD: National Institutes of Health; 1997:19.

5. Rahn EJ, Hohmann AG. Cannabinoids as pharmacotherapies for neuropathic pain: from the bench to the bedside. Neurotherapeutics 2009;6:713-37. Full Text

6. Pertwee RG. Cannabinoid pharmacology: the first 66 years. Br J Pharmacol 2006;147(Suppl 1):163-71. Full Text

7. Malone DT, Hill MN, Rubino T. Adolescent cannabis use and psychosis: epidemiology and neurodevelopmental models. Br J Pharmacol 2010;160:511-22. Full Text

8. Ashtari M, Avants B, Cyckowski L, et al. Medial temporal structures and memory functions in adolescents with heavy cannabis use. J Psychiatr Res 2011;45:1055-66. Full Text

9. Cohen M, Rasser PE, Peck G, et al. Cerebellar greymatter deficits, cannabis use and first-episode schizophrenia in adolescents and young adults. Int $\mathrm{J}$ Neuropsychopharmacol 2012;15:297-307. Full Text

10. Fergusson DM. Is there a causal linkage between cannabis use and increased risks of psychotic symptoms? Addiction 2010;105:1336-7. Full Text

11. Minozzi S, Davoli M, Bargagli AM, Amato L, Vecchi S, Perucci CA. An overview of systematic reviews on cannabis and psychosis: discussing apparently conflicting results. Drug Alcohol Rev 2010;29:304-17. Full Text

12. Foti DJ, Kotov R, Guey LT, Bromet EJ. Cannabis use and the course of schizophrenia: 10-year follow-up after first hospitalization. Am J Psychiatry 2010; 167: 987-93. Full Text 
13. Lev-Ran S, Segev A, Braw Y, Levkovitz Y. Neurocognitive functions of heavy cannabis using schizophrenia patients. Eur Psychiatry 2012;27:365-8. Full Text

14. Solowij N, Battisti R. The chronic effects of cannabis on memory in humans: a review. Curr Drug Abuse Rev 2008;1:81-98. Full Text

15. Han J, Kesner P, Metna-Laurent M, et al. Acute cannabinoids impair working memory through astroglial CB(1) receptor modulation of hippocampal LTD. Cell 2012;148:1039-50. Full Text

16. Yucel M, Solowij N, Respondek C, et al. Regional brain abnormalities associated with long-term heavy cannabis use. Arch Gen Psychiatry 2008;65:694-701. Full Text

17. Honarmand K, Tierney MC, O'Connor P, Feinstein A. Effects of cannabis on cognitive function in patients with multiple sclerosis. Neurology 2011;76:1153-6o. Full Text

18. Schubart CD, Sommer IE, van Gastel WA, Goetgebuer RL, Kahn RS, Boks MP. Cannabis with high cannabidiol content is associated with fewer psychotic experiences. Schizophr Res 2011;130:21621. Full Text

19. Cuhha JM, Carlini EA, Pereira AE. Chronic administration of cannabidiol to healthy volunteers and epileptic patients. Pharmacology 1980;21:175-85. Full Text

20. Yamaori S, Kushihara M, Yamamoto I, Watanabe K. Characterization of major phytocannabinoids, cannabidiol and cannabinol, as isoform-selective and potent inhibitors of human CYP1 enzymes. Biochem Pharmacol 2010;79:1691-8. Full Text

21. Leung L. Cannabis and its derivatives: review of medical use. J Am Board Fam Med 2011;24:452-62. Full Text

22. Devane WA, Breuer A, Sheskin T, Järbe TU, Eisen MS, Mechoulam R. A novel probe for the cannabinoid receptor. J Med Chem 1992;35:2065-9. Full Text

23. Borgelt LM, Franson KL, Nussbaum AM, Wang GS. The pharmacologic and clinical effects of medical cannabis. Pharmacotherapy 2013;33:195-209. Full $\underline{\text { Text }}$

24. Hi HL. An archaeological and historical account of cannabis in China. Econ Bot 1974;28:437-48.

25. Zias J, Stark H, Sellgman J, et al. Early medical use of cannabis. Nature 1993;363:215. Full Text

26. Aggarwal SK, Carter GT, Sullivan MD, ZumBrunnen C, Morrill R, Mayer JD. Medicinal use of cannabis in the United States: historical perspectives, current trends, and future directions. J Opioid Manag 2009; 5:153-68.
27. Mechoulam R. Cannabinoids as Therapeutics. Basel, Switzerland: Birkhauser Verlag; 2005. Full Text

28. Devane WA, Dysarz FA, Johnson MR, Melvin LS, Howlett AC. Determination and characterization of a cannabinoid receptor in rat brain. Mol Pharmacol 1988;34:605-13.

29. Matsuda LA, Stephen JL, Micheal J, Young C, Bonner TI. Structure of a cannabinoid receptor and functional expression of the cloned cDNA. Nature 1990; 346:561-4. Full Text

30. Munro S, Thomas KL, Abu-Shaar M. Molecular characterization of a peripheral receptor for cannabinoids. Nature 1993;365:61-5. Full Text

31. Overington JP, Al-Lazikani B, Hopkins AL. How many drug targets are there? Nat Rev Drug Discov 2006;5:993-6. Full Text

32. Gertsch J. Anti-inflammatory cannabinoids in diet: towards a better understanding of $\mathrm{CB}(2)$ receptor action? Commun Integr Biol 2008;1:S26-8. Full Text

33. Gerard CM, Mollereau C, Vassart G, Parmentier M. Molecular cloning of a human cannabinoid receptor which is also expressed in testis. Biochem J 1991;279: 129-34.

34. Glass M, Faull RLM, Dragunow M. Cannabinoid receptors in the human brain: a detailed anatomical and quantitative autoradiographic study on the fetal, neonatal and adult human brain. Neuroscience 1997;77:299-318. Full Text

35. Ishac EJN, Jiang L, Lake KD, Varga K, Abood ME, Kumos G. Inhibition of exocytotic noradrenaline release by presynaptic cannabinoid $\mathrm{CB} 1$ receptors on peripheral sympathetic nerves. Br J Pharmacol 1996; 118:2023-8. Full Text

36. Galiegue S, Mary S, Marchand J, et al. Expression of central and peripheral cannabinoid receptors in human immune tissues and leukocyte subpopulations. Eur J Biochem 1995;232:54-61. Full Text

37. Rice W, Shannon JM, Burton F, Fiedeldey D. Expression of a brain type cannabinoid receptor (CB1) in alveolar type-II cells in the lung-regulation by hydrocortisone. Eur J Pharmacol 1997;327:22732. Full Text

38. Hulsebosch CE. Special issue on microglia and chronic pain. Exp Neurol 2012;234:253-4. Full Text

39. Beltramo M. Cannabinoid type 2 receptor as a target for chronic pain. Mini Rev Med Chem 2009;9:11-25. Full Text

40. Felder CC, Joyce KE, Briley EM, et al. Comparison of the pharmacology and signal transduction of the human cannabinoid $\mathrm{CB} 1$ and $\mathrm{CB} 2$ receptors. Mol Pharmacol 1995;48:443-50. 
41. Devane WA, Hanus L, Breuer A, et al. Isolation and structure of a brain constituent that binds to the cannabinoid receptor. Science 1992;258:1946-9. Full $\underline{\text { Text }}$

42. Felder CC, Nielsen A, Briley EM, et al. Isolation and measurement of the endogenous cannabinoid receptor agonist, anandamide in brain and peripheral tissues of human and rat. FEBS Lett 1996;393:231-5. Full Text

43. Kozono S, Matsuyama T, Biwasa KK, et al. Involvement of the endocannabinoid system in periodontal healing. Biochem Biophys Res Commun 2010;394: 928-33. Full Text

44. De Petrocellis L, Bisogno T, Maccarrone M, et al. The activity of anandamide at vanilloid VR1 receptors requires facilitated transport across the cell membrane and is limited by intracellular metabolism. J Biol Chem 2001;276:12856-63. Full Text

45. Vogel Z, Barg J, Levy R, Saya D, Heldman E, Mechoulam R. Anandamide, a brain endogenous compound, interacts specifically with cannabinoid receptors and inhibits adenylate cyclase. J Neurochem 1993;61:352-5. Full Text

46. Smith PB, Compton DR, Welch SP, Razdan RK, Mechoulam R, Martin BR. The pharmacological activity of anandamide, a putative endogenous cannabinoid, in mice. J Pharmacol Exp Ther 1994; 270:219-27.

47. Welch SP. Blockade of cannabinoid-induced antinociception by norbinaltorphimine, but not N-N-,diallyltyrosine-Aib-phenylalanine-leucine, ICL 174,864 or naloxone in mice. J Pharmacol Exp Ther 1993;265:633-40.

48. Pertwee RG, Howlett AC, Abood ME, et al. International Union of Basic and Clinical Pharmacology. LXXIX. Cannabinoid receptors and their ligands: beyond CB1 and CB2. Pharmacol Rev 2010; 62:588-631. Full Text

49. Thiago RL, Romero L, Resende LC, Guzzo LS, Duarte IDG. CB1 and CB2 cannabinoid receptor agonists induce peripheral antinociception by activation of the endogenous noradrenergic system. Anesth Analg 2013;116:463-72. Full Text

50. Beltramo M, Bernardini N, Bertorelli R, et al. CB2 receptor-mediated antihyperalgesia: possible direct involvement of neural mechanisms. Eur J Neurosci 2006;23:1530-8. Full Text

51. Van Sickle MD, Duncan M, Kingsley PJ, et al. Identification and functional characterization of brainstem cannabinoid $\mathrm{CB} 2$ receptors. Science 2005;310:329-32. Full Text
52. Jhaveri MD, Elmes SJ, Richardson D, et al. Evidence for a novel functional role of cannabinoid $\mathrm{CB}(2)$ receptors in the thalamus of neuropathic rats. Eur $\mathrm{J}$ Neurosci 2008;27:1722-30. Full Text

53. Anand U, Otto WR, Sanchez-Herrera D, et al. Cannabinoid receptor $\mathrm{CB} 2$ localisation and agonist mediated inhibition of capsaicin responses in human sensory neurons. Pain 2008;138:667-80. Full Text

54. Jhaveri MD, Sagar DR, Elmes SJ, Kendall DA, Chapman V. Cannabinoid CB2 receptor-mediated anti-nociception in models of acute and chronic pain. Mol Neurobiol 2007;36:26-35. Full Text

55. Ibrahim MM, Porreca F, Lai J, et al. CB2 cannabinoid receptor activation produces antinociception by stimulating peripheral release of endogenous opioids. Proc Natl Acad Sci U S A 2005;102:3093-8. Full Text

56. Bushlin I, Rozenfeld R, Devi LA. Cannabinoid-opioid interactions during neuropathic pain and analgesia. Curr Opin Pharmacol 2010;10:80-6. Full Text

57. Nackley AG, Zvonok AM, Makriyannis A, Hohmann AG. Activation of cannabinoid $\mathrm{CB} 2$ receptors suppresses C-fiber responses and windup in spinal wide dynamic range neurons in the absence and presence of inflammation. J Neurophysiol 2004;92: 3562-74. Full Text

58. Quartilho A, Mata HP, Ibrahim MM, et al. Inhibition of inflammatory hyperalgesia by activation of peripheral CB2 cannabinoid receptors. Anesthesiology 2003;99:955-60. Full Text

59. Richardson D, Pearson RG, Kurian N, et al. Characterisation of the cannabinoid receptor system in synovial tissue and fluid in patients with osteoarthritis and rheumatoid arthritis. Arthritis Res Ther 2008;10:R43. Full Text

6o. Walczak JS, Pichette V, Leblond F, Desbiens K, Beaulieu P. Behavioral, pharmacological and molecular characterization of the saphenous nerve partial ligation: a new model of neuropathic pain. Neuroscience 2005;132:1093-102. Full Text

61. Wotherspoon G, Fox A, McIntyre P, Colley S, Bevan $\mathrm{S}$, Winter J. Peripheral nerve injury induces cannabinoid receptor 2 protein expression in rat sensory neurons. Neuroscience 2005;135:235-45. Full Text

62. Brusberg M, Arvidsson S, Kang D, et al. CB1 Receptors mediate the analgesic effects of cannabinoids on colorectal distension-induced visceral pain in rodents. J Neurosci 2009;29:1554-64. Full Text

63. Pertwee RG. Cannabinoid receptors and pain. Prog Neurobiol 2001;63:569-611. Full Text

64. Campbell FA, Tamer MR, Carroll D, et al. Are cannabinoids an effective and safe treatment option in the 
management of pain? A qualitative systemic review. BMJ 2001;323:1-6. Full Text

65. Dogrul A, Seyrek M, Yalcin B, Ulugol A. Involvement of descending serotonergic and noradrenergic pathways in CB1 receptor-mediated antinociception. Prog Neuropsychopharmacol Biol Psychiatry 2012;38:97105. Full Text

66. Iversen L, Chapman V. Cannabinoids: a real prospect for pain relief? Curr Opin Pharmacol 2002;2:50-5. Full Text

67. Abrams DI, Jay CA, Shade SB, et al. Cannabis in painful HIV associated sensory neuropathy: a randomized placebo-controlled trial. Neurology 2007; 68:515-21. Full Text

68. Notcutt W, Price M, Miller A, et al. Initial experiences with medicinal extracts of cannabis for chronic pain: results from 34 ' $\mathrm{N}$ of 1' studies. Anaesthesia 2004; 59:440-52. Full Text

69. Karst M, Salim K, Burstein S, et al. Analgesic effect of the synthetic cannabinoid CT-3 on chronic neuropathic pain: a randomized controlled trial. JAMA 2003;290:1757-62. Full Text

70. Zajicek JP, Sanders HP, Wright DE, et al. Cannabinoids in multiple sclerosis (CAMS) study: safety and efficacy data for 12 months follow up. J Neurol Neurosurg Psychiatry 2005;76:1664-9. Full Text

71. Svendsen KB, Jensen TS, Bach FW. Does the cannabinoid dronabinol reduce central pain in multiple sclerosis? Randomised double blind placebo controlled crossover trial. BMJ 2004;329:253. Full $\underline{\text { Text }}$

72. Wade DT, Makela PM, House H, et al. Long-term use of a cannabis based medicine in the treatment of spasticity and other symptoms in multiple sclerosis. Mult Scler 2006;12:639-45. Full Text

73. Rog DJ, Nurmiko T, Friede T, et al. Randomized controlled trial of cannabis based medicine in central neuropathic pain due to multiple sclerosis. Neurology 2005;65:812-19. Full Text

74. Wade DT, Robson P, House H, et al. A preliminary controlled study to determine whether whole-plant cannabis extracts can improve intractable neurogenic symptoms. Clin Rehabil 2003;17:18-26. Full Text

75. Berman JS, Symonds C, Birch R. Efficacy of two cannabis based medicinal extracts for relief of central neuropathic pain from brachial plexus avulsion: results of a randomised controlled trial. Pain 2004; 112:299-306. Full Text

76. Nurmikko TJ, Serpell MG, Hoggart B, et al. Sativex successfully treats neuropathic pain characterised by allodynia: a randomised, doubleblind, placebo-controlled clinical trial. Pain 2007;133:210-20. Full Text

77. Blake DR, Robson P, Ho M, Jubb RW, et al. Preliminary assessment of the efficacy, tolerability and safety of a cannabis-based medicine (Sativex) in the treatment of pain caused by rheumatoid arthritis. Rheumatology (Oxford) 2006;45:50-2. Full Text

78. Michalski CW, Laukert T, Sauliunaite D, et al. Cannabinoids ameliorate pain and reduce disease pathology in cerulein-induced acute pancreatitis. Gastroenterology 2007;132:1968-78. Full Text

79. Lee MC, Ploner M, Wiech K, et al. Amygdala activity contributes to the dissociative effect of cannabis on pain perception. Pain 2013;154:124-34. Full Text

80. Gaoni Y, Mechoulam R. Isolation, structure and partial synthesis of an active constituent of hashish. Journal of the American Chemical Society 1964;86: 1646-7. Full Text

81. Buggy DJ, Toogood L, Maric S, Sharpe P, Lambert DG, Rowbotham DJ. Lack of analgesic efficacy of oral delta-9-tetrahydrocannabinol in postoperative pain. Pain 2003;106:169-72. Full Text

82. Holdcroft A, Smith M, Jacklin A, et al. Pain relief with oral cannabinoids in familial Mediterranean fever. Anaesthesia 1997;52:483-6. Full Text

83. Naef M, Curatolo M, Petersen-Felix S, Arendt-Nielsen L, Zbinden A, Brenneisen R. The analgesic effect of oral delta-9-tetrahydrocannabinol (THC), morphine, and a THC-morphine combination in healthy subjects under experimental pain conditions. Pain 2003;105: 79-88. Full Text

84. Lemberger L, Row H. Clinical pharmacology of nabilone, a cannabinol derivative. Clin Pharm 1975; 18:720-6.

85. Skrabek RQ, Galimova L, Ethans K, Perry D. Nabilone for the treatment of pain in fibromyalgia. $\mathrm{J}$ Pain 2008;9:164-73. Full Text

86. Beaulieu P. Effects of nabilone, a synthetic cannabinoid, on postoperative pain. Can J Anaesth 2006;53: 769-75. Full Text

87. Mechoulam R, Parker LA, Gallily R. Cannabidiol: an overview of some pharmacological aspects. J Clin Pharmacol 2002;42:11S-19S.

88. Leweke FM, Piomelli D, Pahlisch F, et al. Cannabidiol enhances anandamide signaling and alleviates psychotic symptoms of schizophrenia. Transl Psychiatry 2012;2:1-7.

89. Thomas A, Baillie GL, Phillips AM, et al. Cannabidiol displays unexpectedly high potency as an antagonist 
of $\mathrm{CB} 1$ and $\mathrm{CB} 2$ receptor agonists in vitro. $\mathrm{Br} \mathrm{J}$ Pharmacol 2007;150:613-23. Full Text

90. Morgan C, Curran H. Effects of cannabidiol on schizophrenia-like symptoms in people who use cannabis. Br J Psychiatry 2008;192:306-7. Full Text

91. Morgan C. Impact of cannabidiol on the acute memory and psychotomimetic effects of smoked cannabis: naturalistic study. Br J Psychiatry 2010; 197:285-90. Full Text

92. Iskedjian M, Bereza B, Gordon A, Piwko C, Einarson TR. Meta-analysis of cannabis based treatments for neuropathic and multiple sclerosis-related pain. Curr Med Res Opin 2007;23:17-24. Full Text

93. Russo EB. Cannabinoids in the management of difficult to treat pain. Ther Clin Risk Manag 2008;4: 245-59.

94. Ellis RJ, Toperoff W, Vaida F, et al. Smoked medicinal cannabis for neuropathic pain in HIV: a randomized crossover clinical trial. Neuropsychopharmacology 2009;34:672-80. Full Text

95. Wallace M, Schulteis G, Atkinson JH, et al. Dosedependent effects of smoked cannabis on capsaicininduced pain and hyperalgesia in healthy volunteers. Anesthesiology 2007;107:785-96. Full Text

96. Wilsey B, Marcotte T, Tsodikov A, et al. A randomized, placebo controlled, crossover trial of cannabis cigarettes in neuropathic pain. J Pain 2008;9:506-21. Full Text

97. Wilsey B, Marcotte T, Deutsch R, Gouaux B, Sakai S, Donaghe H. Low-dose vaporized cannabis significantly improves neuropathic pain. J Pain 2013;14: 1236-48. Full Text

98. Gieringer D, St. Laurent J, Goodrich S. Cannabis combines efficient delivery of THC with effective suppression of pyrolytic compounds. J Cannabis Ther 2004;4:2-27. Full Text

99. Michalski CW, Oti FE, Erkan M, et al. Cannabinoids in pancreatic cancer: correlation with survival and pain. Int J Cancer 2008;122:742-50. Full Text

100. Farquhar-Smith WP. Do cannabinoids have a role in cancer pain management? Curr Opin Support Palliat Care 2009;3:7-13. Full Text

101. Johnson J, Burnell-Nugent M, Lossignol D, GanaeMotan ED, Potts R, Fallon MT. Multicenter, doubleblind, randomized, placebo-controlled, parallel-group study of the efficacy, safety, and tolerability of THC:CBD extract and THC extract in patients with intractable cancer-related pain. J Pain Symptom Manage 2010;39:167-79. Full Text

102. Zhornitsky S, Potvin S. Cannabidiol in humans-the quest for therapeutic targets. Pharmaceuticals 2012; 5:529-52. Full Text
103. Russo EB. Taming THC: potential cannabis synergy and phytocannabinoid-terpenoid entourage effects. Br J Pharmacol 2011;163:1344-64. Full Text

104. Trevaskis NL, Shackleford DM, Charman WN, et al. Intestinal lymphatic transport enhances the postprandial oral bioavailability of a novel cannabinoid receptor agonist via avoidance of first-pass metabolism. Pharm Res 2009;26:1486-95. Full Text

105. Gertsch J, Pertwee RG, Di Marzo V. Phytocannabinoids beyond the Cannabis plant - do they exist? Br J Pharmacol 2010;160:523-9. Full Text

106. Comelli F, Giagnoni G, Bettoni I, Colleoni M, Costa B. Antihyperalgesic effect of Cannabis sativa extract in a rat model of neuropathic pain: mechanisms involved. Phytother Res 2008;22:1017-24. Full Text

107. Gertsch J, Leonti M, Raduner S, et al. Betacaryophyllene is a dietary cannabinoid. Proc Natl Acad Sci U S A 2008;105:9099-114. Full Text

108.Zimmer A, Racz I, Klauke AL, Markert A, Gertsch J. Betacaryophyllene, a phytocannabinoid acting on $\mathrm{CB} 2$ receptors. IACM $5^{\text {th }}$ Conference on cannabinoids in medicine, 2009, Cologne, Germany. Available at: http://tinyurl.com/nlfozjg. Accessed March 23, 2013.

109. Dinarello CA. Immunolgical and inflammatory functions of the interleukin-1 family. Annu Rev Immunol 2009;27:519-50. Full Text

110. Cichewicz DL, McCarthy EA. Antinociceptive synergy between delta(9)-tetrahydrocannabinol and opioids after oral administration. J Pharmacol Exp Ther 2003;304:1010-15. Full Text

111. Zutler M, Holty JC. Opioids, sleep and sleepdisordered breathing. Curr Pharm Des 2011;17:14439. Full Text

112. Carley DW, Pavlovic S, Janelidze M, Radulovacki M. Functional role of cannabinoids in respiratory stability during sleep. Sleep 2002;25:388-95.

113. Huestis MA. Pharmacokinetics and metabolism of the plant cannabinoids, delta9-tetrahydrocannabinol, cannabidiol and cannabinol. Handb Exp Pharmacol 2005;168:657-90. Full Text

114. Walker JM, Huang SM. Cannabinoid analgesia. Pharmacol Ther 2002;95:127-35. Full Text

115. Schwilke EW, Schwope DM, Karschner EL, et al. Delta 9-tetrahydrocannabinol (THC), 11-hydroxyTHC, and 11-nor-9-carboxy-THC plasma pharmacokinetics during and after continuous high-dose oral THC. Clin Chem 2009;55:2180-9. Full Text

116. Burns TL, Ineck JR. Cannabinoid analgesia as a potential new therapeutic option in the treatment of chronic pain. Ann Pharmacother 2006;40:251-60. Full Text 